\title{
THE INFLUENCE OF TECHNOLOGY ACCEPTANCE MODEL (TAM) AND BRAND TRUST TOWARD CONSUMER'S INTENTION TO BUY IN TIKET.COM WITH E-WOM AS A MODERATING VARIABLE
}

\author{
Oey Rachel Cathleen Wijaya ${ }^{1}$, Clarissa Listya Susilo ${ }^{2 *}$ \\ ${ }^{1,2}$ Tourism Department, Faculty of Tourism, Universitas Ciputra Surabaya, Indonesia \\ ${ }^{*}$ Corresponding Author's e-mail: clarissa.susilo@ciputra.ac.id
}

\begin{abstract}
The growing number of online travel agent in Indonesia, pushed tiket.com to compete in increasing its application brand performance and consumer's perception. This research uses a quantitative method to test the hypothesis regarding Technology Acceptance Model and Brand Trust with E-WOM as a moderating variable. The population of this research is Indonesian consumer that had ever want or made a purchase in tiket.com. The sampling technique used in this research is non-probability sampling method with 110 as its number of respondents. This research used Hierarchical Regression Analysis as its data analysis technique. Based on the test that was done, the results showed that technology acceptance model had a positive and significant effect towards consumer's intention to buy and brand trust had a positive and significant effect towards consumer's intention to buy. The result also showed that e-WOM as a moderating variable has a positive but insignificant effect in the relationship between brand trust and consumer's intention to buy, which means e-WOM as a moderating variable has a strengthening effect although the effect is insignificant in the relationship between brand trust and consumer's intention to buy in tiket.com.
\end{abstract}

Keywords: Technology Acceptance Model; Brand Trust; E-WOM; Intention to Buy

\section{INTRODUCTION}

According to Statistics Indonesia (2020), the number of tourist who visited Indonesia in 2018 was 303.403 .888 people. This amount of tourists increased by $12 \%$ in comparison to the number of tourists who visited Indonesia in 2017 , which was 270.822 .003 people. Based on the report that was released by World Economic Forum (2019), Indonesia's competitiveness 
Index in tourism sectors experienced an increased with the overall score of 4.3. Based on this report, it can be seen that Indonesia ranks 40 form 140 other countries in the competitiveness index in the tourism sector. The grow in Indonesia's tourism sector is also supported by the existence of online based travel agent or OTA such as Traveloka, Tiket.com, Pegi-pegi, and many more. The global growth of digital tour and travel industry from 2016-2025 is predicted to contribute US\$305 billion in profitability.

In Indonesia, there are quite a lot of Online Travel Agent platform that provides not only airplane ticket but also hotel bookings and many other services. Some of these platforms are: Traveloka, Tiket.com, Pegi-pegi, Booking.com and many more. The increasing amount of Online Travel Agent (OTA) in Indonesia causes an increase in the competition between these OTAs. The object of this research is Tiket.com, which was the first Online Travel Agent in Indonesia. Based on the data that was released by Zebua (2018), Tiket.com ranks second in consumer's choice when buying an airplane ticket, after Traveloka. Since the object of this research is travel agent who uses online platform, it is important to understand the influence of Technology Acceptance Model towards consumer's intention to buy. Memarzadeh et al. (2016) mention that e-comments in the online hotel service review are a useful source of information for business traveler to choose a hotel room. This statement also supports the finding by Falaahuddin \& Widiartanto (2020) which stated that usefulness has a significant effect towards intention to buy. In the same research Falaahuddin \& Widiartanto (2020) also mention that ease of use has a significant effect towards intention to buy. Which means when it comes to the user of KAl Access Application, the higher the perception of ease of use, the higher it is the intention to buy. Also, there aren't a lot of research in regard to the influence of TAM towards intention to buy especially in the tourism fields, therefore this research also aims to diversify the knowledge regarding TAM and intention to buy, especially in tourism related research objects.

TAM is an abbreviation from Technology Acceptance Model. According to Lederer et al. (2000), TAM proposes that ease of use and usefulness predicts application use. This model is often used to measure how the user of a technology accepts and use the technology. 
According to Pavlou (2003) Technology Acceptance Model has two indicators, these indicators are perceived usefulness and perceived ease of use. According to Venkatesh \& Davis (2000) perceived usefulness can be defined as a belief that is owned by an individual regarding the use of technology which he/she believed to increase his/her capacity. Perceived usefulness can also be defined as individual perception regarding the benefit of an activity (Basyar \& Sanaji, 2018). This research uses perceived usefulness indicators from Sun \& Zhang (2006): system usage can help the user's activity to become easier; system usage can increase the user's capacity/ability; system usage can help to increase a user's productivity; and system usage can provide a benefit for its user. Ease of use can be defined as a condition in which the user believe that he/she doesn't need a lot of effort in operating a system due to its easy usage. This research uses perceived ease of use indicators from Davis (1989), which are: the system can easily be accessed by the user; the system can easily be used by the user; and the system can easily be learned by the user.

Considering the increasing competition between OTAs, it is also important to understand how brand trust influence consumer's intention to buy in Tiket.com and the role moderating of e-word of mouth in affecting a consumer's brand trust and intention to buy. In his research Sapti (2019) concluded that brand trust has an effect towards intention to buy, this conclusion also goes in accordance with the result from Suhardi \& Irmayanti (2019) which mentioned that brand trust has a positive effect towards intention to buy. Brand trust has a significant effect towards the continuity of the brand, therefore if a brand is no longer trusted by the customer it will be hard or the product that is trusted by the brand to grow in the market. Brand trust itself can be defined as a customer's behavior that shows his/her willingness to be dependent to a brand that he/she consider able to reflect the function of that product. Lau \& Lee (1999) mentioned that the emergence of customer's trust towards a brand can be affected by 3 factors. These factors are the image of the brand; the image of the company which creates the brand; and the image of the customer. Ballester \& Munuera-Alemán (2001) explains there are 2 indicators in brand trust: brand reliability and brand intention. The reliability of a brand based on how far does the customer's trust that the brand is able to fulfil its promises and help 
to complete their needs and gives satisfaction to the consumer. Brand reliability is very important for a company because, trust in a brand emerge when a brand is able to fulfil its promises - this caused the consumer to believe that they are able to get their needs. Brand intention is based on a consumer's trust that a brand will put its consumer's interest first before the company's interest when a problem occur during the usage of the product / service.

The effect of word of mouth as a moderating variable can be seen from the research by Jaini et al. (2019), this research finds that strong e-WOM has strong moderating effect in the relationship between personal norm and green purchase behavior. Hennig-Thurau et al. (2004) defined e-WOM as a statement both positive and negative which was written by the prospective customer, customer as well as previous customer regarding a product/company, where this information can be found by customers and institutions through information media. Bambauer-Sachse \& Mangold (2011) explains that e-WOM can be measured using general persuasive, general credibility and product's vulnerability towards online reviews. According to Goyette et al. (2010) there are a few indicators that can be used to measure e-WOM: intensity; valance of opinion; and content.

Based on the discussions above, below can be seen the proposed model of this research

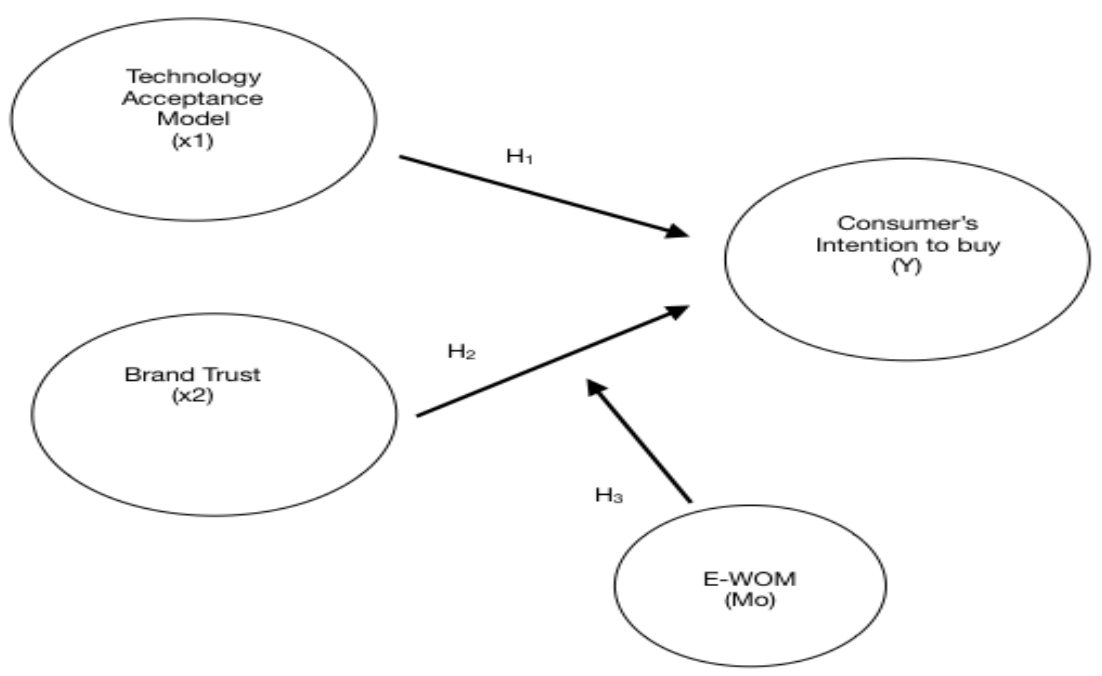

Figure 1. Research Model 


\subsection{Hypotheses}

Based on the model above, this research aims to understand whether (1) Technology Acceptance Model has an influence towards consumer's intention to buy in tiket.com, (2) Brand Trust has an influence towards consumer's intention to buy in tiket.com, and (3) e-WOM as a moderating variable strengthen the influence of brand trust towards consumer's intention to buy in Tiket.com. Therefore, based on the aims above, this research proposes three hypotheses:

H1. Technology Acceptance Model has an influence towards consumer's intention to buy in Tiket.com

H2. Brand Trust has an influence towards consumer's intention to buy in Tiket.com

H3. E-WOM as a moderating variable strengthen the influence of brand trust towards consumer's intention to buy in Tiket.com

\section{METHODS}

This research uses a quantitative method as its research methodology. Sugiyono (2016) defined quantitative method as a method that is based on the positivism philosophy and being used to research a certain population / sample using research instruments which aims to test the proposed hypothesis. The population of this research is Indonesian customer who has ever want or has made a purchase in Tiket.com (example, flight ticket, hotel reservation, train ticket, entrance ticket to. Events or attraction) This research uses a non-probability sampling with purposive sampling as its sampling technique. The sample of this research was customer who has ever want or has made a purchase in Tiket.com. The amount of sample used in this research was 110 persons, which was determined using theory from Hair et al. (2014).

This research uses primary data in a form of questionnaire that had been given to the respondents using an online form. Each indicator in this questionnaire was measured using a 4 point Likert scale. This research uses SPSS to analyze the data. In using SPSS, there are several test that was used in order to analyze the data. These tests were validity test, reliability 
test, hierarchical regression analysis, $T$ test, correlation coefficient $(R)$, coefficient of determination test and classical assumption tests.

\section{RESULT AND DISCUSSION}

Based on the data taken from the questionnaire, among the 110 respondents $61.3 \%$ were female while the other $38.7 \%$ were male and all $100 \%$ of the respondents stated 'they are interested in making purchases at Tiket.com'. Based on the Pearson correlation validity test that was done using SPSS, it can be concluded that all the variable in this research are valid. Based on the reliability test that was done using SPSS, it can also be concluded that all the variable in this research has a Cronbach Alpha of more than 0.6 which means all the variable used in this research are reliable.

The $p$-value value in the normality test was 0.107 which was larger than 0.05 . Therefore, it can be concluded that the data used in this research has a normal distribution. Based on the Spearman's rho test that was conducted, it can be seen that the sig. (2-tailed) value of the TAM variable (0.893), brand trust variable $(0.770)$ and e-WOM variable $(0.908)$ was bigger than 0.05 therefore it can be said that there is no heteroscedasticity problem in this research. The significance value in the linearity test was 0.000 which was smaller than 0.05 . This shown that technology acceptance model variable and consumer's intention to buy variable has a linear relationship. The same thing can also be seen in the significancy value in the linearity test for brand trust variable and consumer's intention to buy variable where the significance value was 0.000 . This meant brand trust variable and consumer's intention to buy variable has a linear relationship. Last but not least, the significancy value in the linearity test was 0.000 which was smaller than 0.05 . This means that brand trust variable and consumer's intention to buy with e-WOM as a moderating variable has a linear relationship.

This research uses t-test in order to understand the significance level of the independent variable towards the dependent variables. 
Table 1. T-Test Results

\begin{tabular}{|c|c|c|c|c|c|c|}
\hline \multicolumn{2}{|r|}{ Model } & \multicolumn{2}{|c|}{$\begin{array}{l}\text { Unstandardized } \\
\text { Coefficients }\end{array}$} & \multirow{2}{*}{$\begin{array}{c}\text { Standardized } \\
\text { Coefficients } \\
\text { Beta }\end{array}$} & \multirow[t]{2}{*}{$\mathrm{t}$} & \multirow[t]{2}{*}{ Sig. } \\
\hline & & B & Std. Error & & & \\
\hline \multirow[t]{3}{*}{1} & (Constant) & -0.057 & 0.347 & & -0.166 & 0.869 \\
\hline & x1_Mn & 0.406 & 0.117 & 0.292 & 3.458 & 0.001 \\
\hline & x2_Mn & 0.575 & 0.099 & 0.493 & 5.838 & 0.000 \\
\hline \multirow[t]{4}{*}{2} & (Constant) & 0.048 & 0.308 & & 0.155 & 0.877 \\
\hline & x1_Mn & 0.268 & 0.107 & 0.193 & 2.501 & 0.014 \\
\hline & x2_Mn & 0.456 & 0.090 & 0.391 & 5.059 & 0.000 \\
\hline & Mo_Mn & 0.273 & 0.050 & 0.377 & 5.489 & 0.000 \\
\hline \multirow[t]{5}{*}{3} & (Constant) & 0.046 & 0.310 & & 0.149 & 0.881 \\
\hline & x1_Mn & 0.268 & 0.108 & 0.193 & 2.494 & 0.014 \\
\hline & x2_Mn & 0.456 & 0.091 & 0.391 & 5.039 & 0.000 \\
\hline & Mo_Mn & 0.271 & 0.051 & 0.375 & 5.359 & 0.000 \\
\hline & $a b c$ & 0.006 & 0.031 & 0.011 & 0.181 & 0.857 \\
\hline
\end{tabular}

a. Dependent Variable: y_Mn

Based on the T-test result above, it can be seen that the sig. value of TAM (X1) was 0.014 which was smaller than 0.05 thus it can be concluded that technology acceptance model (TAM) (X1) has a significant impact towards consumer's intention to buy (Y). Therefore it can be said that the first hypothesis of this research which is 'Technology Acceptance Model has an influence towards consumer's intention to buy in Tiket.com' was accepted. The result also suggest that an increase of value in the technology acceptance model (TAM) variable can also increase the value of consumer's intention to buy variable, this results also corresponds with the results from Widhiani \& Idris (2018) which stated that the indicator 'ease of use in TAM can affect a user's intention to buy when they're doing a purchase'. Also based on the result above, it can be seen that the sig. value of brand trust $(x 2)$ was 0.000 which was smaller than 0.05 thus it can be concluded that brand trust (X2) has a significant impact towards 
consumer's intention to buy $(\mathrm{Y})$. Therefore it can be said that the second hypothesis of this research which is 'Brand Trust has an influence towards consumer's intention to buy in Tiket.com' was accepted. The result also suggests that an increase of value in the brand trust variable can also increase the value of consumer's intention to buy variable, this result also corresponds with the result from Suhardi \& Irmayanti (2019) which stated that 'brand trust variable can affect a consumer's intention to buy when they're doing a purchase'. From the result above, it can be seen that the sig. value of moderation result was 0.857 which was larger than 0.05 thus it can be concluded that e-WOM has a non-significant strengthening moderating effect in the relationship between brand trust (X2) and consumer's intention to buy $(\mathrm{Y})$.

Coefficient correlation in this research is used to understand how strong the relationship between the independent and the dependent variable.

Table 2. $R$ and $R$ Square $\left(R^{2}\right)$ Results

\begin{tabular}{|c|c|c|c|c|}
\hline Model & R & R Square & Adjusted R Square & $\begin{array}{c}\text { Std. Error of the } \\
\text { Estimate }\end{array}$ \\
\hline 1 & $0.706^{\mathrm{a}}$ & 0.499 & 0.490 & 0.38981 \\
\hline 2 & $0.780^{\mathrm{b}}$ & 0.609 & 0.598 & 0.34594 \\
\hline 3 & $0.780^{\mathrm{c}}$ & 0.609 & 0.594 & 0.34751 \\
\hline
\end{tabular}

a. Predictors: (Constant), x2_Mn, x1_Mna.

b. Predictors: (Constant), x2_Mn, x1_Mn, Mo_Mnb.

c. Predictors: (Constant), x2_Mn, x1_Mn, Mo_Mn, ab

Based on the result above, it can be seen that the coefficient correlation $(R)$ has a value of 0.780 or $78 \%$. Therefore, it can be said that the dependent variable in this research was affected by the independent variable for as much as $78 \%$. Then from the table above, it can also be seen that the $R$ square value was 0.609 which means the independent variables used 
in this research can predict the dependent variable for as much as $60.9 \%$ while the other $39.1 \%$ was affected by other factors.

\section{CONCLUSIONS}

Based on the result of the tests that was done, it can be concluded that TAM has a positive and significant effect towards consumer's intention to buy in Tiket.com. This means as the technology acceptance model (TAM) goes higher, the consumer's intention to buy will also goes higher. Brand trust has a positive and significant effect towards consumer's intention to buy in Tiket.com. This means as the brand trust goes higher, the consumer's intention to buy will also goes higher. E-WOM as a moderating variable has a positive but insignificant effect in the relationship between brand trust and consumer's intention to buy in Tiket.com. This means e-WOM as a moderating variable strengthen the relationship but the strengthening effect was not that strong / significant.

\section{REFERENCES}

Ballester, E. D., \& Munuera-Alemán, J.-L. (2001). Brand trust in the context of consumer loyalty. European Journal of Marketing, 35(11/12), 1238-1258. https://doi.org/10.1108/eum0000000006475

Bambauer-Sachse, S., \& Mangold, S. (2011). Brand equity dilution through negative online word-of-mouth communication. Journal of Retailing and Consumer Services, 18(1), 3845. https://doi.org/10.1016/j.jretconser.2010.09.003

Basyar, K., \& Sanaji, S. (2018). Pengaruh persepsi kemudahan dan persepsi manfaat terhadap niat beli ulang secara online dengan kepuasan sebagai variabel intervening. BISMA (Bisnis Dan Manajemen), 8(2), 204. https://doi.org/10.26740/bisma.v8n2.p204217

Davis, F. D. (1989). Perceived usefulness, perceived ease of use, and user acceptance of information technology. MIS Quarterly: Management Information Systems, 13(3), 319339. https://doi.org/10.2307/249008

Falaahuddin, A. A., \& Widiartanto. (2020). Pengaruh persepsi kegunaan, persepsi kemudahan, dan keamanan terhadap minat beli pengguna aplikasi mobile KAI Access. Jurnal Administrasi Bisnis, 9(3), 295-301.

https://ejournal3.undip.ac.id/index.php/jiab/article/view/28084

Goyette, I., Ricard, L., Bergeron, J., \& Marticotte, F. (2010). E-WOM scale: Word-of-mouth measurement scale for e-services context. Canadian Journal of Administrative Sciences, 27(1), 5-23. https://doi.org/10.1002/cjas.129

Hair, J. F. J., Black, W. C., Babin, B. J., \& Anderson, R. E. (2014). Multivariate data analysis. Exploratory data analysis in business and economics. In British Library Cataloguing-inPublication Data (7th ed.). Pearson Education Limited.

Hennig-Thurau, T., Gwinner, K. P., Walsh, G., \& Gremler, D. D. (2004). Electronic word-of- 
mouth via consumer-opinion platforms: What motivates consumers to articulate themselves on the Internet? Journal of Interactive Marketing, 18(1), 38-52. https://doi.org/10.1002/dir.10073

Jaini, A., Quoquab, F., Mohammad, J., \& Hussin, N. (2019). "I buy green products, do you...?": The moderating effect of eWOM on green purchase behavior in Malaysian cosmetics industry. International Journal of Pharmaceutical and Healthcare Marketing, 14(1), 89-112. https://doi.org/10.1108/lJPHM-02-2019-0017

Lau, G. T., \& Lee, S. H. (1999). Consumers' trust in a brand and the link to brand loyalty. Journal of Market-Focused Management, 4(4), 341-370. https://doi.org/10.1023/A:1009886520142

Lederer, A. L., Maupin, D. J., Sena, M. P., \& Zhuang, Y. (2000). Technology acceptance model and the World Wide Web. Decision Support Systems, 29(3), 269-282. https://doi.org/10.1016/S0167-9236(00)00076-2

Memarzadeh, F., Blum, S. C., \& Adams, C. (2016). Business travelers' intention to purchase: The application of Technology Acceptance Model (TAM). Journal of Quality Assurance in Hospitality and Tourism, 17(4), 412-424. https://doi.org/10.1080/1528008X.2015.1096755

Pavlou, P. A. (2003). Consumer acceptance of electronic commerce: Integrating trust and risk with the technology acceptance model. International Journal of Electronic Commerce, 7(3), 101-134. https://doi.org/10.1080/10864415.2003.11044275

Sapti, M. (2019). Pengaruh iklan dan kepercayaan merek terhadap minat beli konsumen (Studi pada Texas Chicken Pekanbaru). Kemampuan Koneksi Matematis (Tinjauan Terhadap Pendekatan Pembelajaran Savi), 53(9), 1689-1699.

Statistics Indonesia. (2020). Jumlah perjalanan wisatawan nusantara (orang), 2017-2019. https://doi.org/10.1055/s-2008-1040325

Sugiyono. (2016). Metode penelitan kuantitatif, kualitatif dan R\&D. In Alfabeta. Alfabeta.

Suhardi, D., \& Irmayanti, R. (2019). Pengaruh celebrity endorser, citra merek, dan kepercayaan merek terhadap minat beli konsumen. Jurnal Inspirasi Bisnis Dan Manajemen, 3(1), 53. https://doi.org/10.33603/jibm.v3i1.2086

Sun, H., \& Zhang, P. (2006). The role of moderating factors in user technology acceptance. International Journal of Human Computer Studies, 64(2), 53-78. https://doi.org/10.1016/j.ijhcs.2005.04.013

Venkatesh, V., \& Davis, F. D. (2000). Theoretical extension of the Technology Acceptance Model: Four longitudinal field studies. Management Science, 46(2), 186-204. https://doi.org/10.1287/mnsc.46.2.186.11926

Widhiani, A., \& Idris. (2018). Pengaruh promosi, kemudahan penggunaan, kepercayaan konsumen dan kualitas informasi terhadap minat beli di situs Buka Lapak (Pada mahasiswa Universitas Diponegoro). Diponegoro Journal Ofmanagement, 7(2), 1-6.

World Economic Forum. (2019). Travel and Tourism Competitiveness Report 2019 - Reports - World Economic Forum. In Travel \& Tourism Competitiveness Index. http://reports.weforum.org/travel-and-tourism-competitiveness-report-2019/countryprofiles/\#economy=MEX

Zebua, F. (2018). Online Travel Agencies (OTA) survey 2018. https://dailysocial.id/research/online-travel-agencies-ota-survey-2018 